\title{
Relation between Body Size and Bone Mineral Density with special reference to Sex Hormones and Calcium Regulating Hormones in Elderly Females
}

\author{
Masataka SHIRAKI, Hideki ITO*, Hiroshi FUJIMAKI* and \\ TATSUO HIGUCHI** \\ Department of Laboratory Medicine, *Section of Endocrinology \\ and Metabolism, and ** Section of Gynecology, Tokyo Metropolitan \\ Geriatric Hospital, Tokyo 173, Japan
}

\begin{abstract}
We studied the relation between body size and bone mineral density in elderly females. The study included a total of 93 ambulatory females aged over 60 years. They were divided into 3 groups according to their body mass index $\left(\mathrm{BMI} ; \mathrm{kg} / \mathrm{m}^{2}\right)$ : slender group with $\mathrm{BMI}<20(\mathrm{n}=28)$, normal group with BMI of 20 to $24.9(n=43)$ and obese group with $B M I \geqq 25(n=22)$. Fracture incidence, bone mineral density, calcium regulating hormones and steroid hormones were studied in an intergroup comparative manner. The incidence of vertebral fracture was found to be negatively correlated with BMI (the incidences of vertebral fracture in slender, normal and obese were 78.6, 48.8 and $22.7 \%$, respectively) and bone mineral density was also BMI-related $\left(0.390 \pm 0.016,0.456 \pm 0.015\right.$ and $0.493 \pm 0.018 \mathrm{~g} / \mathrm{cm}^{2}$, respectively: $p<0.01$ in ANOVA; mean \pm SE). The number of years after menopause was shorter in patients with a higher BMI. There was no intergroup difference in serum levels of PTH, vitamin D and estrogens. On the other hand, serum levels of calcitonin, DHEA, DHEAS, delta- 4 androstenedione and testosterone were found to be higher in subjects with a higher BMI. From the present results, it seems that bone mineral density is supported not only by weight-bearing stress upon bone, but also by serum levels of calcitonin and androgens in obese females.
\end{abstract}

Key words: Body size, Bone mineral, Elderly females, Sex steroids, Calcium regulating hormones.

(Endocrinol Japon 38: 343-349, 1991)

IT HAD BEEN well accepted that body size is one of the major determinants of actual bone mineral density [1-3]. Possible reasons for the correlation between ponderosity and bone mineral density are the following: (1) peak bone mass is greater in obese people than in slender people, (2) body size and bone size are greater in obese people than in slender people, (3) mechanical stress acting on bone is greater in obese people than in slender people, (4) obese people have some metabolic advantages in maintaining bone mineral content.

Received: January 8, 1991

Accepted: June 3, 1991

Correspondence to: Dr. Masataka SHIRAKI, Department of Laboratory Medicine, Tokyo Metropolitan Geriatric Hospital, 35-2 Sakae-cho, Itabashi-ku, Tokyo 173, Japan.
Bell et al. [4] were the first to report that hormonal factors such as secondary hyperparathyroidism associated with a higher serum level of active vitamin $\mathrm{D}$ may account for the higher $\mathrm{BMD}$ in young obese people than in slender people. In general, the serum level of PTH increases with age $[5,6]$, and the production of 1, 25-dihydroxyvitamin $\mathrm{D}\left(1,25-(\mathrm{OH})_{2} \mathrm{D}\right)$ in kidney decreases with age $[7,8]$. Despite the abnormal calcium regulating mechanisms in the elderly, the higher bone mineral density still exists in elderly obese people [2].

The aim of the present study was therefore to clarify what mechanisms contribute to the maintenance of bone mineral density in obese elderly females. 


\section{Subjects and Methods}

\section{Subjects}

The present study included a total of 93 postmenopausal women aged 60 to 89 years $(75 \pm 1.0$ years; mean $\pm \mathrm{SEM})$. All the subjects were ambulatory, and those having diseases and medications which might affect their calcium metabolism were excluded. The body mass index (BMI) $\left(\mathrm{Kg} / \mathrm{m}^{2}\right)$ was calculated and these subjects were divided into three types of body size according to the criteria of Bray [9]: the slender type (group 1 with a BMI of less than $20 ; n=28$ ), the normal type (group 2 with a BMI of 20 to $24.9 ; n=43$ ) and the obese type (group 3 with a BMI of 25 or above; $n=22$ ).

Measurement of Radial Mineral Density (RMD) and confirmation of vertebral fracture

Radial mineral density (RMD) was measured at a level $1 / 3$ distal to the left radius by the method previously reported $[10,11]$ with a Norland bone mineral analyzer, Model 278A (Norland Co., WI, USA). Vertebral X-ray pictures were taken in all subjects to confirm the presence or absence of vertebral fracture. Briefly, we measured the posterior and anterior height of the vertebral body in Th2 to L5. If the posterior/anterior height ratio ( $\mathrm{P} / \mathrm{A}$ ratio) was larger than 1.4 , we diagnosed it as a fracture. In the present study, 49 women $(52.7 \%)$ had vertebral fracture(s). None of these fractured subjects had a history of severe trauma, therefore, the vertebral fracture(s) seen in the present cases were considered to be fragility fracture.

\section{Serum biochemistry}

$15 \mathrm{ml}$ of whole blood and urine were collected following an overnight fast every month for 4 months (a total of $60 \mathrm{ml}$ of blood was taken from each of the subjects). Then whole blood was divided into two parts: $5 \mathrm{~m} l$ of blood was utilized for the measurement of serum levels of calcium (Ca), phosphorus (P), BUN, creatinine and Al-P activities (Al-P) and the serum obtained from the remaining $10 \mathrm{~m} l$ of whole blood was pooled for the assay of serum levels of steroid hormones, gonadotropins and calcium regulating hormones. Urine samples were measured for fasting urinary excretion of $\mathrm{Ca}, \mathrm{P}$ and creatinine, and the $\mathrm{Ca} /$ creatinine ratio $(\mathrm{Ca} / \mathrm{Cr})$ and $\mathrm{P} /$ creatinine ratio $(\mathrm{P} / \mathrm{Cr})$ were calculated. The mean values for the four measurements of serum $\mathrm{Ca}, \mathrm{P}, \mathrm{BUN}$, creatinine and $\mathrm{Al}-\mathrm{P}$, and urinary $\mathrm{Ca} / \mathrm{Cr}$ and $\mathrm{P} / \mathrm{Cr}$ ratios were taken as data representative of each individual. $\mathrm{Ca}, \mathrm{P}$, creatinine, $\mathrm{BUN}$ and $\mathrm{Al}-\mathrm{P}$ were measured by automated colorimetric assay (Toshiba $80-\mathrm{S}$, Toshiba ME, Tokyo, Japan). Serum levels of vitamin $\mathrm{D}$ metabolites were measured by the methods previously reported $[10,12,13]$. Briefly, 25-hydroxyvitamin D (25-OH-D) and 24, 25dihydroxyvitamin $\mathrm{D}\left(24,25-(\mathrm{OH})_{2} \mathrm{D}\right)$ were extracted from serum and were purified by column chromatography (LH-20) and then measured by competitive protein binding assay. The purified fraction corresponding to 1, 25-dihydroxyvitamin D $\left(1,25-(\mathrm{OH})_{2} \mathrm{D}\right)$ was applied to radioreceptor assay. The reference values for these vitamin D metabolites in elderly women were 13 to $39 \mathrm{ng} / \mathrm{m} l$ for $25-\mathrm{OH}-\mathrm{D}, 1.0$ to $3.3 \mathrm{ng} / \mathrm{ml}$ for $24,25-(\mathrm{OH})_{2} \mathrm{D}$ and 11 to $55 \mathrm{pg} / \mathrm{ml}$ for $1,25-(\mathrm{OH})_{2} \mathrm{D}$.

The serum level of parathyroid hormone (PTH) was measured with an Eiken PTH-C RIA kit which can detect mainly the C-terminal fragment(s) of PTH [12, 13]. The reference value for PTH in elderly females is 0.16 to $0.55 \mathrm{ng} / \mathrm{ml}$. For calcitonin (CT) measurement, a human CT RIA kit (Daiichi Radioisotope Co., Ltd., Osaka, Japan) was used. The lower limit of detection of this kit is $20 \mathrm{pg} / \mathrm{m} l$ and intra- and inter-assay variances in our laboratory are $22.0 \%$ and $18.5 \%(n=25)$, respectively. The normal level of CT was less than $185 \mathrm{pg} / \mathrm{ml}$. For luteinizing hormone (LH) and follicule stimulating hormone $(\mathrm{FSH})$, radioimmunoassay kits (Daiichi Radioisotope Co., Ltd., Osaka, Japan) were used. The reference values for $\mathrm{LH}$ and $\mathrm{FSH}$ in elderly females are $61.2 \pm 6.6 \mathrm{mIU} / \mathrm{m} l$ and $78.3 \pm 7.8 \mathrm{mIU} / \mathrm{m} l$ (Mean $\pm \mathrm{SD})$, respectively. Steroid hormones were determined by specific radioimmunoassay for each steroid hormone in Teikokuzoki Clinical Laboratories (Kanagawa, Japan). Serum dehydroepiandrosterone sulfate (DHEAS) and cortisol were measured by direct assay with serum with intra- and inter-assay variances of 7.5 and $11.5 \%$ for DHEAS $(n=5)$, and 13.7 and $17.8 \%$ for cortisol. DHEA and testosterone were extracted with ether and then applied to the radioimmunoassays, and the residues were applied to LH-20 column chromatography (solvent; hexane: benzene: methanol=91: 1: 7) and then the fraction coincided to each steroid hormone was assayed by specific radioimmunoassay. Through these procedures, the recoveries for 
17-OH-pregnenolone, 17-OH-progesterone, delta-4 androstenedione, estrone (E1), estradiol (E2) and aldosterone were 63.4, 80.4, 74.1, 83.2, 74.7 and $71.3 \%$, respectively. The assay sensitivities of $\mathrm{E} 1$ and $\mathrm{E} 2$ were $10 \mathrm{pg} / \mathrm{ml}$. When $\mathrm{E} 2$ was undetectable, the serum E2 levels were described as 10 $\mathrm{pg} / \mathrm{ml}$. A cross reaction of each specific antiserum to various steroids was less than $10 \%$ except for the antiserum raised to $17-\mathrm{OH}$-progesterone which strongly cross-reacts with cortisol $(92.3 \%$ crossreaction). On the other hand, the antiserum to cortisol did not crossreact with $17-\mathrm{OH}-$ progesterone. Therefore, we measured serum levels of 17-OH-progesterone after the extraction and purification procedure and the serum cortisol level was measured by direct assay [14]. The intraand inter-assay variances of these extracted and purified steroid hormone radioimmunoassays were less than $15 \%$.

\section{Statistical analysis}

ANOVA or $\chi^{2}$-test was used for intergroup comparison. Student's $t$-test (two-tailed) was also used for the comparison between two groups. All the data are expressed as the mean \pm SEM.

\section{Results}

\section{Background factors}

Table 1 summarizes the background factors of the subjects. There were no significant intergroup differences with regard to the means of age, body height, Al-P, BUN and creatinine in the three groups. A significant intergroup difference was noted in the number of years after menopause in a BMI-related manner $(\mathrm{p}<0.05$ in ANOVA). This difference was mainly explained by the difference between groups 1 and $3(\mathrm{p}<0.01$ in Student's $t$-test).

\section{Bone parameters}

The incidence of vertebral fracture was found to vary according to BMI (Fig. $1 ; \chi^{2}=15.631$, $\mathrm{p}<0.01$ ). Radial mineral density (RMD) was found to increase $(p<0.01$ in ANOVA) as BMI increases. RMDs in groups 1,2 and 3 were $0.390 \pm 0.016$, $0.456 \pm 0.015$ and $0.493 \pm 0.018 \mathrm{~g} / \mathrm{cm}^{2}$, respectively. Significant differences in RMD between groups 1 and 2, and groups 1 and 3 ( $\mathrm{p}<0.01$ in Student's $t$-test) were found (Fig. 1).

\section{Calcium metabolism}

There were no intergroup differences with regard to serum levels of $\mathrm{Ca}, \mathrm{P}, \mathrm{PTH}$ and vitamin $\mathrm{D}$ metabolites. The fasting urinary $\mathrm{Ca} / \mathrm{Cr}$ ratio tended to decrease with the increase in BMI. The serum CT level increased as the BMI increased $(\mathrm{p}<0.01$ in ANOVA and $\mathrm{p}<0.01$ in Student's $t$-test between groups 1 and 3) (Table 2).

\section{Steroid hormones}

Table 3 summarizes intergroup differences in serum levels of steroid hormones, LH and FSH. Serum levels of androgens such as DHEA, DHEAS, delta- 4 androstenedione and testoster-

Table 1. Background data of the subjects

\begin{tabular}{llcccl}
\hline Items & & Group 1 & Group 2 & Group 3 & Significance \\
\hline Age & $(\mathrm{y} . \mathrm{o})$. & $75.5 \pm 1.0$ & $75.3 \pm 0.9$ & $72.8 \pm 1.7$ & N.S. \\
Body weight & $(\mathrm{Kg})$ & $38.4 \pm 0.7$ & $47.8 \pm 1.2$ & $58.5 \pm 1.1$ & $\mathrm{p}<0.01$ \\
Body height & $(\mathrm{cm})$ & $143.6 \pm 1.2$ & $146.0 \pm 1.0$ & $145.8 \pm 0.8$ & N.S. \\
Body mass index & $\left(\mathrm{Kg} / \mathrm{m}^{2}\right)$ & $18.5 \pm 0.2$ & $22.3 \pm 0.3$ & $27.5 \pm 0.8$ & $\mathrm{p}<0.01$ \\
Duration after & & & & & \\
$\quad$ menopause & $($ year $)$ & $29.8 \pm 1.5$ & $26.1 \pm 1.2$ & $22.6 \pm 2.1 * *$ & $\mathrm{p}<0.05$ \\
Al-P & $(\mathrm{IU})$ & $40.3 \pm 2.2$ & $39.0 \pm 1.7$ & $37.6 \pm 1.8$ & N.S. \\
BUN & $(\mathrm{mg} / \mathrm{d} l)$ & $18.6 \pm 1.0$ & $18.4 \pm 0.6$ & $17.6 \pm 0.9$ & N.S. \\
Creatinine & $(\mathrm{mg} / \mathrm{d} l)$ & $0.9 \pm 0.04$ & $0.9 \pm 0.03$ & $0.9 \pm 0.04$ & N.S. \\
Number of cases & & 28 & 43 & 22 & \\
& & & & &
\end{tabular}

The classification criteria of the subjects are the following: Slender (Group 1), BMI $<20$;

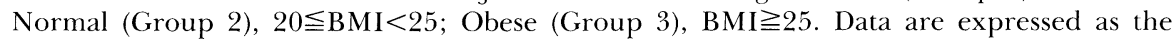
mean \pm SEM. Statistical analyses are performed with ANOVA in the case of multi-group comparison and with Student's $t$-test in the case of two-group comparison. "Significance" means the level of significance in ANOVA. **; $\mathrm{p}<0.01$ vs Group 1 (Slender) in Student's $t$-test. 


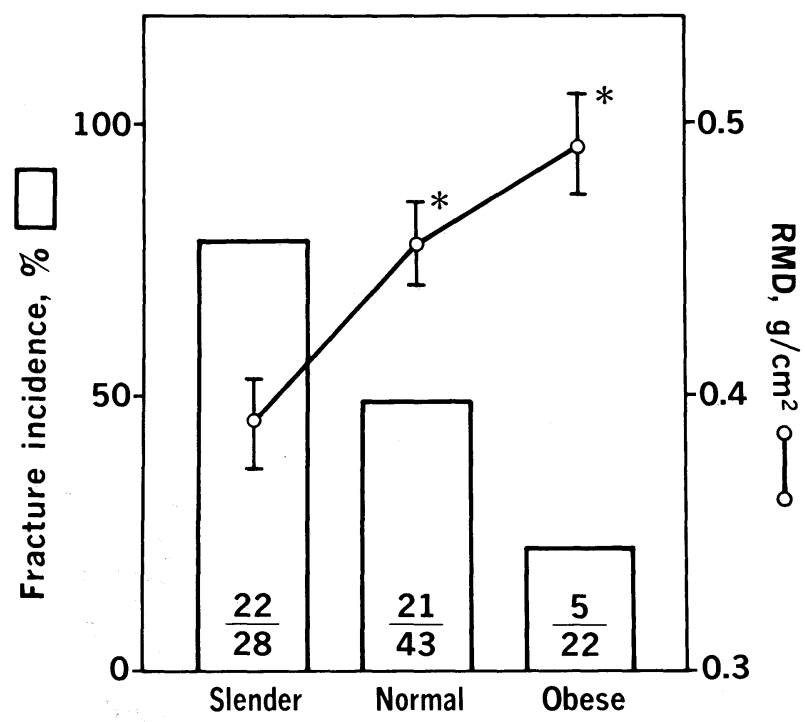

Fig. 1. Incidence of vertebral fracture(s) and radial mineral density in elderly females.

Vertebral X-ray pictures were taken in all subjects to determine the presence or absence of vertebral fracture. The measurement of the P/A ratio for each vertebral body was performed by the doctor (M.S.) without specifying the name of the subject. The number of subjects with vertebral fracture and the total number of subjects in each class of ponderosity are shown in the Figure. The incidence of vertebral fracture was found to vary according to the BMI $\left(\mathrm{p}<0.01\right.$ in $\chi^{2}$-test). The radial mineral density in each category of BMI is also shown. There was a significant increase in RMD in accordance with the increase in the BMI $(\mathrm{p}<0.01$ in ANOVA and $* \mathrm{p}<0.01$ between slender and normal groups, and slender and obese groups in Student's $t$-test). one were increased as the BMI increased $(p<0.05-0.01$ in ANOVA). However, there was no intergroup difference with regard to the other steroid hormones such as estrogens, glucocorticoid and mineral corticoid. The significant differences in serum levels of androgens in the 3 groups were mainly responsible for the differences between groups 1 and 2, because the significant differences in androgen levels were observed only between groups 1 and 2 but not between groups 2 and 3 . However, the serum testosterone level of group 1 was significantly lower than that of group 3 $(\mathrm{p}<0.05$ in Student's $t$-test $)$. There was no significant difference between the serum testosterone level in group 1 and that in 2 .

Coefficients of correlation between RMD and serum levels of hormones

Table 4 shows the coefficients of correlation between body size, age and serum levels of hormones, and RMD. Age, body size, calcitonin and androgens levels were highly correlated with RMD.

\section{Discussion}

One of the facts demonstrated in the present study is that serum levels of PTH and 1,25$(\mathrm{OH})_{2} \mathrm{D}$ do not change in elderly women regardless of ponderosity. This fact largely differed from the results reported by Bell et al. [4], in young subjects. A possible explanation for this discrepan-

Table 2. Calcium metabolism of the subjects

\begin{tabular}{lccccl}
\hline Items & & Group 1 & Group 2 & Group 3 & Significance \\
\hline Serum Ca & $(\mathrm{mg} / \mathrm{d} l)$ & $9.3 \pm 0.1$ & $9.2 \pm 0.1$ & $9.1 \pm 0.1$ & N.S. \\
Serum P & $(\mathrm{mg} / \mathrm{d} l)$ & $3.7 \pm 0.1$ & $3.5 \pm 0.1$ & $3.5 \pm 0.1$ & N.S. \\
U-Ca/Cr. & & $0.125 \pm 0.013$ & $0.129 \pm 0.013$ & $0.083 \pm 0.014^{*}, \#$ & N.S. \\
U-P/Cr. & & $0.548 \pm 0.043$ & $0.535 \pm 0.033$ & $0.430 \pm 0.030^{*, \#}$ & N.S. \\
PTH & $(\mathrm{ng} / \mathrm{m} l)$ & $0.40 \pm 0.03$ & $0.38 \pm 0.03$ & $0.39 \pm 0.04$ & N.S. \\
CT & $(\mathrm{pg} / \mathrm{m} l)$ & $63.5 \pm 7.3$ & $84.2 \pm 6.0$ & $117.4 \pm 8.0^{* * * \# \#}$ & p $<0.01$ \\
$25-(\mathrm{OH})-\mathrm{D}$ & $(\mathrm{ng} / \mathrm{m} l)$ & $19.0 \pm 1.5$ & $19.0 \pm 1.0$ & $23.9 \pm 1.4^{* . \# \#}$ & N.S. \\
$24,25(\mathrm{OH})_{2} \mathrm{D}$ & $(\mathrm{ng} / \mathrm{m} l)$ & $1.6 \pm 0.2$ & $1.4 \pm 0.2$ & $1.3 \pm 0.1$ & N.S. \\
$1,25(\mathrm{OH})_{2} \mathrm{D}$ & $(\mathrm{pg} / \mathrm{m} l)$ & $49.7 \pm 4.2$ & $43.0 \pm 2.7$ & $48.8 \pm 3.9$ & N.S. \\
Number of cases & & 28 & 43 & 22 & \\
\hline
\end{tabular}

$\mathrm{U}-\mathrm{Ca} / \mathrm{Cr}$. and U-P/Cr. mean urinary calcium and phosphorus/creatinine ratios, respectively. Data are expressed as the mean \pm SEM and statistical analyses are performed with ANOVA in the case of multigroup comparison, and with Student's $t$-test in the case of two-group comparison. "Significance" means the significance level in ANOVA. **; $\mathrm{p}<0.01, * ; \mathrm{p}<0.05$ in Student's $t$-test vs Group 1 (Slender) and \#\#; $<<0.01$, \#; $\mathrm{p}<0.05$ vs Group 2 (Normal). 
Table 3. Relation between physique and serum levels of steroid hormones

\begin{tabular}{llclll}
\hline Items & & Group 1 & Group 2 & Group 3 & Significance \\
\hline LH & $(\mathrm{mIU} / \mathrm{m} l)$ & $97.8 \pm 6.6$ & $98.6 \pm 6.9$ & $77.2 \pm 6.4^{* * *}$ & N.S. \\
FSH & $(\mathrm{mIU} / \mathrm{m} l)$ & $106.2 \pm 7.0$ & $99.4 \pm 5.8$ & $82.5 \pm 6.6^{*}$ & N.S. \\
17-OH-progesterone & $(\mathrm{ng} / \mathrm{ml})$ & $0.37 \pm 0.04$ & $0.43 \pm 0.04$ & $0.55 \pm 0.12$ & N.S. \\
17-OH-pregnenolone & $(\mathrm{ng} / \mathrm{m} l)$ & $1.42 \pm 0.18$ & $1.60 \pm 0.04$ & $1.85 \pm 0.12$ & N.S. \\
DHEA & $(\mathrm{ng} / \mathrm{m} l)$ & $1.40 \pm 0.13$ & $2.11 \pm 0.16^{* *}$ & $2.43 \pm 0.23^{* *}$ & $\mathrm{p}<0.01$ \\
DHEAS & $(\mathrm{ng} / \mathrm{ml})$ & $323 \pm 43$ & $624 \pm 51^{* *}$ & $680 \pm 85^{* *}$ & $\mathrm{p}<0.01$ \\
$\triangle^{4}$-androstenedione & $(\mathrm{ng} / \mathrm{ml})$ & $0.43 \pm 0.04$ & $0.68 \pm 0.05^{* *}$ & $0.79 \pm 0.10^{* *}$ & $\mathrm{p}<0.01$ \\
testosterone & $(\mathrm{ng} / \mathrm{ml})$ & $0.38 \pm 0.03$ & $0.44 \pm 0.03$ & $0.49 \pm 0.03$ & $\mathrm{p}<0.05$ \\
estrone & $(\mathrm{pg} / \mathrm{ml})$ & $53.9 \pm 4.9$ & $58.1 \pm 5.2$ & $57.7 \pm 5.7$ & N.S. \\
estradiol & $(\mathrm{pg} / \mathrm{ml})$ & $21.1 \pm 2.3$ & $23.0 \pm 2.0$ & $23.4 \pm 1.7$ & N.S. \\
aldosterone & $(\mathrm{pg} / \mathrm{m} l)$ & $108 \pm 12$ & $130 \pm 20$ & $103 \pm 10$ & N.S. \\
cortisol & $(\mathrm{ng} / \mathrm{ml})$ & $204 \pm 13$ & $195 \pm 9$ & $173 \pm 10$ & N.S. \\
Number of case & & 28 & 43 & 22 & \\
\hline
\end{tabular}

The methods of assays for these items are presented in the text. Data are expressed as the mean \pm SEM and statistical analyses are performed with ANOVA in the case of multigroup comparison and with Student's $t$-test in the case of two-group comparison. "Significance" means the level of significance in ANOVA. **; $p<0.01, * ; p<0.05$ in Student's $t$-test vs Group 1 (Slender) and $\# ;$ p $<0.05$ vs Group 2 (Normal).

Table 4. Correlation coefficients between radial mineral density (RMD) and age, body size and hormones

\begin{tabular}{|c|c|c|}
\hline Category of items & \multicolumn{2}{|c|}{ Correlation coefficients for RMD } \\
\hline Age & $r=-0.430$ & $(\mathrm{p}<0.01)$ \\
\hline BMI & $r=0.407$ & $(\mathrm{p}<0.01)$ \\
\hline \multicolumn{3}{|c|}{ Calcium regulating hormones } \\
\hline Calcitonin & $r=0.346$ & $(\mathrm{p}<0.01)$ \\
\hline PTH & $\mathrm{r}=-0.055$ & N.S, \\
\hline $1,25-(\mathrm{OH})_{2} \mathrm{D}$ & $r=0.023$ & N.S. \\
\hline \multicolumn{3}{|l|}{ Gonadotropins } \\
\hline $\mathrm{LH}$ & $\mathrm{r}=-0.206$ & $(\mathrm{p}=0.05)$ \\
\hline FSH & $\mathrm{r}=-0.247$ & $(\mathrm{p}<0.02)$ \\
\hline \multicolumn{3}{|l|}{ Steroid hormones } \\
\hline 17-OH-progesterone & $r=0.174$ & N.S. \\
\hline 17-OH-pregnenolone & $\mathrm{r}=0.295$ & $(\mathrm{p}<0.01)$ \\
\hline DHEA & $r=0.421$ & $(\mathrm{p}<0.01)$ \\
\hline DHEAS & $\mathrm{r}=0.505$ & $(\mathrm{p}<0.01)$ \\
\hline$\triangle 4$-androstenedione & $\mathrm{r}=0.431$ & $(\mathrm{p}<0.01)$ \\
\hline Testosterone & $\mathrm{r}=0.303$ & $(\mathrm{p}<0.01)$ \\
\hline Estrone & $\mathrm{r}=0.123$ & N.S. \\
\hline Estradiol & $\mathrm{r}=0.138$ & N.S. \\
\hline Aldosterone & $\mathrm{r}=-0.002$ & N.S. \\
\hline Cortisol & $\mathrm{r}=-0.183$ & N.S. \\
\hline
\end{tabular}

The correlation coefficients of age, body size and hormonal parameter for radial mineral density were calculated in 93 elderly females. Highly significant positive correlations between serum levels of androgens and RMD are found. 
cy is the difference in the degree of obesity. In fact, our obese subjects in the present study were mostly people who belonged to the overweight range (maximum body weight and BMI were 78 $\mathrm{Kg}$ and $35 \mathrm{Kg} / \mathrm{m}^{2}$, respectively), while the subjects reported by Bell et al. were from the overweight to the morbidly obese. Therefore, it is possible that secondary hyperparathyroidism with higher production of $1,25-(\mathrm{OH})_{2}$-D can be observed only in morbid obesity.

In the present study, calcitonin (CT) was the only calcium regulating hormone that was significantly related with BMI and with RMD. CT is known to be a potent inhibitor of bone resorption [15], so the difference in the serum level of CT may partly explain the intergroup difference in bone mineral density found among the three groups.

In the present study, we measured serum levels of steroid hormones in relation to the ponderosity of the subjects. It has been widely accepted that the serum level of estrogens plays an important role in the diminishment of bone mineral density in females around menopause $[16,17]$. However, it is still not clear whether estrogens play an important role in elderly females in relation to their bone mineral density. Serum estrogens in women after menopause derive from the peripheral conversion of androgens produced by the adrenal glands. This process of converting androgens to estrogens is catalyzed by aromatase which is located in muscles and in fat tissues [18]. Therefore, it is possible that obese elderly women have higher serum levels of estrogens because of the greater amount of the converting enzyme [19] which they have. However, the serum levels of estrogens did not differ in accordance with their ponderosity. Furthermore, there was no significant correlation between the serum estrogen levels and RMD. The fact that there were no significant intergroup differences in the serum levels of gonadotropins (LH and FSH) was consistent with the absence of a difference in the estrogen levels. In spite of these negative findings, we think that estrogens may contribute somewhat to the maintenance of bone mineral density in elderly females, since the obese group had fewer years after menopause, and a lower fracture incidence and larger RMD than those in slender subjects. This fact may mean that the serum levels of estrogens are more important in the menopause than in the elderly phase. In addition, we have to pay attention to the assay sensitivity in estradiol radioimmunoassay, because $15 \%$ (14 out of 93 cases) of the present subjects had less than $10 \mathrm{pg} / \mathrm{ml}$ estradiol in the serum which was the minimal detectable limit in the present assay. Nine cases in whom the serum estradiol level could not be measured belonged to group 1. Thus, it is possible that the serum level of estradiol may be much lower than in the present results in group 1 . We cannot therefore imply that estrogens play no significant role in the maintenance of BMD in elderly females.

On the other hand, the present results clearly demonstrated the signfiicant difference in serum levels of androgens in a BMI-related manner. Furthermore, these androgen levels significantly correlated with RMD. These results are in good agreement with previous reports indicating that serum androgens are more greatly decreased in patients with osteoporosis than in age-matched controls [20, 21]. Recently, it has been reported that androgens promote osteoblastic proliferation [22]. Thus, androgens may play an important role in bone mineral metabolism in elderly females.

In conclusion, we found that even in elderly females, body size is a determinant factor in bone mineral density. The possible contributing factors for higher bone mineral density in obese subjects might include late menopause and higher serum levels of CT as well as androgens.

\section{Acknowledgements}

This work was partly supported by the project for Bone Aging of Tokyo Metropolitan Institute on Gerontology.

\section{References}

1. Dalen N, Hallberg D, Lamke B (1975) Bone mass in obese subjects. Acta Med Scand 197: 353-355.

2. Rundgren A, Eklund E, Jonson R (1984) Bone mineral content in 70- and 75-year-old men and women. An analysis of some anthropometric background factors. Age and Aging 13: 6-13. 
3. Saville PD (1970) Observation on 80 women with osteoporotic spine fractures. In: Barzel US (ed) Osteoporosis, Grune \& Stratton, New York, pp 38-46.

4. Bell NH, Epstein S, Greene A, Shary J, Oexmann MJ, Shaw S (1985) Evidence for alteration of the vitamin $\mathrm{D}$ endocrine system in obese subjects. $J$ Clin Invest 76: 370-373.

5. Wiske PS, Epstein E, Bell NH, Queener SF, Edmondson J, Johnston Jr CC (1979) Increases in immunoreactive parathyroid hormone with age. New Engl J Med 300: 1419-1421.

6. Insogna $\mathrm{KL}$, Lewis AM, Lipinski BA, Bryant C, Baran DT (1981) Effect of age on serum immunoreactive parathyroid hormone and its biological effects. J Clin Endocrinol Metab 53: 1072-1075.

7. Tsai KS, Heath H, Kumar R, Riggs BL (1984) Impaired vitamin D metabolism with aging in women; possible role in pathogenesis of senile osteoporosis. J Clin Invest 73: 1668-1672.

8. Riggs BL, Melton III LJ (1986) Involutional osteoporosis. New Engl J Med 314: 1676-1686.

9. Bray GA (1979) Obesity in America. Int J Obesity 3: 363-364.

10. Shiraki M, Orimo H, Ito H, Akiguchi I, Nakao J, Takahashi R, Ishizuka S (1985) Long-term treatment of postmenopausal osteoporosis with active vitamin $\mathrm{D}_{3}, \quad 1$-alpha-hydroxycholecalciferol $(1 \alpha$ $\left.\mathrm{OH}-\mathrm{D}_{3}\right)$ and 1,24-dihydroxycholecalciferol $\left(1,24(\mathrm{OH})_{2} \mathrm{D}_{3}\right)$. Endocrinol Japon 32: 305-315.

11. Nakao J, Orimo H, Ooyama T, Shiraki M (1979) Low serum estradiol levels in subjects with arterial calcification. Atherosclerosis 34: 469-474.

12. Shiraki M, Miyagawa A, Akiguchi I, Ito H, Ohkawa S, Sugiura M (1988) Evidence of hypovitaminosis $\mathrm{D}$ in patients with mitral ring calcification. Jpn Heart J 29: 801-808.

13. Mori S, Shiraki M, Fujimaki H, Ito H (1987) Bone fracture in elderly female with primary hyperparathyroidism; Relation among renal function, vitamin D status and fracture risk. Horm Metab Res 19: 183-185.

14. Yoshida T, Takamori K, Inatomi K, Ozaki H,
Takagi S, Makino T, Kanbegawa A (1974) Radioimmunoassay for sex-steroid Part VI; Radioimmunoassay for delta-4-androstenedione. Horumon to Rinsho (Clin Endocrinol Tokyo) 22: 671-677.

15. Raisz LG Nieman I (1967) Early effects of parathyroid hormone and thyrocalcitonin in organ culture. Nature 214: 486-487.

16. Slemenda C, Hui SL, Longcope C Johnston Jr CC (1987) Sex steroids and bone mass. J Clin Invest 80: 1261-1269.

17. Richelson LS, Wahner HW, Melton III LJ, Riggs BL (1984) Relative contribution of aging and estrogen deficiency to postmenopausal bone loss. New Engl J Med 311: 1273-1275.

18. Longcope C, Pratt JH, Schneider SH, Fineberg SE (1978) Aromatization of androgens by muscle and adipose tissue in vivo. J Clin Endocrinol Metab 46: 146-152.

19. Frumar AM, Meldrum DR, Geola F, Shamonki IM, Tataryn IV, Deftos DJ, Judd HL (1980) Relationship of fasting urinary calcium to circulating estrogen and body weight in postmenopausal women. I Clin Endocrinol Metab 50: 70-75.

20. Nordine BEC, Robertson A, Seamark RF, Bridges A, Philcox JC, Need AG, Horowitz H, Morris HA, Deam S (1985) The relation between calcium absorption, serum dehydroepiandrosterone and vertebral mineral density in postmenopausal women. J Clin Endocrinol Metab 60: 651-657.

21. Crilly, RG, Horsman A, Marshall DH, Nordin BEC (1978) Post-menopausal and corticosteroidinduced osteoporosis. Front Horm Res 5: 53-75.

22. Kasperk CH, Wergedal JE, Farley JR, Linkhart TA, Turner RT, Baylink DJ (1989) Androgens directly stimulate proliferation of bone cells in vitro. Endocrinol 124: 1576-1578.

23. Nelson DA, Kleerekoper M, Parfitt AM (1988) Bone mass, skin color and body size among black and white women. Bone and Mineral 4: 257-264.

24. Parker L, Gral T, Perrigo V, Skowski R (1981) Decreased adrenal androgen sensitivity to ACTH during aging. Metabolism 30: 601-604. 